\title{
Effects of Cutting after Continuous Grafting on Photosynthetic Physiology of Lycopersicon esculentum seedlings under Cadmium Stress
}

\author{
Hongyan Li ${ }^{1, a}$, Xun Wang ${ }^{1, b}$, Lisha Zhong ${ }^{2, \mathrm{c}}$ and Lijin Lin ${ }^{1, \mathrm{~d}^{*}}$ \\ ${ }^{1}$ Institute of Pomology and Olericulture, Sichuan Agricultural University, Chengdu, Sichuan, China \\ ${ }^{2}$ College of Chemistry and Life Science, Chengdu Normal University, Chengdu, Sichuan, China \\ a1432350417@qq.com, b35744023@qq.com, ‘645627089@qq.com, dllj800924@163.com
}

${ }^{*}$ Corresponding author. Hongyan Li and Xun Wang contributed equally to this work.

Keywords: Lycopersicon esculentum; Continuous grafting; Photosynthesis physiology

Abstract: The effects of cutting after continuous grafted on the photosynthesis physiology of Lycopersicon esculentum seedlings under cadmium $(\mathrm{Cd})$ stress were studied by the pot experiment, and the photosynthetic pigment contents, photosynthetic characteristics and soluble sugar content of $L$. esculentum seedlings were determined. Under $\mathrm{Cd}$ stress, continuous grafting decreased the chlorophyll $a$, chlorophyll $b$, total chlorophyll and carotenoid contents of L. esculentum seedlings with Cyphomandra betacea compared with the un-grafted plants (CK). The one-grafted (G1), two-grafted (G2) and three-grafted (G3) decreased the net photosynthetic rate (Pn), transpiration rate (Tr), stomatal conductance (Gs), $\mathrm{CO}_{2}$ concentration of intercellular (Ci) of L. esculentum seedlings, and decreased the value of pressure deficit leaf (Vpdl) of that compared with CK. Compared with CK, the continuous grafting increased the soluble sugar contents in roots, stems, leaves and shoots of $L$. esculentum seedlings. Therefore, cutting after continuous grafted is unfavorable for the growth of the L. esculentum seedlings under Cd stress.

\section{Introduction}

Lycopersicon esculentum is one of the most important vegetables and cash crops in the word [1]. Grafting is commonly used in practical technology vegetable production, which can cultivate excellent varieties growing stronger, higher yield and resistance to various diseases, and it can overcome the L. esculentum continuous cropping obstacle and diseases [2]. At present, there are few studies on the effects of multiple grafting on plant growth, and some studies have been done on Juglans regia [3]. The heavy metal polluted vegetable gardens have affected the production of $L$. esculentum, especially the cadmium (Cd) [4]. The $\mathrm{Cd}$ is the most bio-toxic heavy metal elements, and has strong chemical activity, fluidity and toxicity in the environment, which inhibits the growth of plants, especially in high Cd concentration, and the structure of tissues was obviously deformed [5]. In this study, L. esculentum seedlings as scions were treated with continuous grafting on Cyphomandra betacea, and then cutting the shoots and planted into soil. The effects of cutting after continuous grafted on the photosynthesis physiology of L. esculentum seedlings were studied, and the photosynthetic pigment contents, photosynthetic characteristics and soluble sugar content of $L$. esculentum seedlings were determined, which could provide the reference for L. esculentum production.

\section{Materials and Methods}

Materials. The Inceptisol soil samples (purple soil in the Genetic Soil Classification of China) were collected from the Chengdu campus farm of Sichuan Agricultural University $\left(30^{\circ} 42^{\prime} \mathrm{N}, 103^{\circ} 51^{\prime} \mathrm{E}\right)$ in April 2017. The basic properties of the soil were $\mathrm{pH} 6.94$, organic matter $17.54 \mathrm{~g} / \mathrm{kg}$, total nitrogen $3.63 \mathrm{~g} / \mathrm{kg}$, total phosphorus $0.38 \mathrm{~g} / \mathrm{kg}$, total potassium $17.54 \mathrm{~g} / \mathrm{kg}$, alkali soluble nitrogen 195.00 $\mathrm{mg} / \mathrm{kg}$, available phosphorus $6.25 \mathrm{mg} / \mathrm{kg}$ and available potassium $191.13 \mathrm{mg} / \mathrm{kg}$. The total Cd content was $0.103 \mathrm{mg} / \mathrm{kg}$, and the bioavailable cadmium (Cd) content was $0.022 \mathrm{mg} / \mathrm{kg}$ [6]. The grafting $L$. 
esculentum seedlings was prepared by the preliminary experiment, the seedlings were grafted in the soil bowl, and there were four treatments in the experiment, un-grafted (CK), one-grafted(G1), two-grafted (G2) and three-grafted (G3). $5 \mathrm{~cm}$ stems of rootstock seedlings (C. betacea) were selected, and $3 \mathrm{~cm}$ sections of L. esculentum grafting were used for grafting. When the grafting was completed, the soil moisture content was maintained at $80 \%$ of field capacity, and all of the seedlings were covered with transparent plastic film and a shade net. After $10 \mathrm{~d}$, the transparent plastic film, the shade net and the plastic binding film were removed, and all the germinating buds of rootstocks were also removed.

Experimental Design. The soil samples were air dried and sieved to $5 \mathrm{~mm}$ in May 2017, then 3.0 $\mathrm{kg}$ of the air-dried soil was weighed into polyethylene pots $(15 \mathrm{~cm}$ tall, $18 \mathrm{~cm}$ diameter), and Cd was added to the soils as $\mathrm{CdCl}_{2} \cdot 2.5 \mathrm{H}_{2} \mathrm{O}$ at $10 \mathrm{mg} / \mathrm{kg}$ [7]. The soil moisture content was maintained at $80 \%$ of field capacity for 4 weeks, and then the soil in each pot was mixed. In May, 2017, the L. esculentum seedlings were cutting into each pot. Each treatment was repeated three times making a total of 12 pots, and put in a completely randomized design with $10 \mathrm{~cm}$ spacing between pots. The soil moisture content was maintained at $80 \%$ of field capacity until the plants were harvested. Two months after planting (July 2017), the photosynthesis of each plant was determined by using LI-6400 portable photosynthesis meter (LI-COR Inc, USA). The photosynthetic parameters of the photosynthesis meters were manual control $\mathrm{CO}_{2}$ concentration $400 \mu \mathrm{mol} / \mathrm{mol}$, temperature $30^{\circ} \mathrm{C}$ and light intensity $1000 \mu \mathrm{mol} / \mathrm{m}_{2} / \mathrm{s}$. The determination of photosynthetic parameters were net photosynthetic rate $(\mathrm{Pn})$, transpiration rate $(\mathrm{Tr})$, stomatal conductance $(\mathrm{Gs}), \mathrm{CO}_{2}$ concentration of intercellular $(\mathrm{Ci})$ and value of pressure deficit leaf $(\mathrm{Vpdl})$, and each treatment was repeated three times. After that, the upper mature leaves of plants were collected to determine the photosynthetic pigment (chlorophyll a, chlorophyll b, total chlorophyll and carotenoid) contents [8]. $0.200 \mathrm{~g}$ cut into pieces of leaf samples were soaked by $20 \mathrm{ml}$ mixed solution of ethanol and acetone $(1: 1, \mathrm{v} / \mathrm{v})$ in the dark condition for $24 \mathrm{~h}$, and then, measured the absorbencies at 663,645 , and $470 \mathrm{~nm}$ for chlorophyll a, chlorophyll b, and carotenoid, and calculated the chlorophyll a, chlorophyll b, total chlorophyll, and carotenoid contents. Then, the whole plants were then gently removed, the roots, stems and leaves were washed with tap water followed by deionized water, and dried at $80{ }^{\circ} \mathrm{C}$ to constant weight. The soluble sugar contents of L. esculentum were determined by anthrone colorimetry with dry weight plant samples [8].

Statistical Analyses. Statistical analyses were conducted using SPSS 13.0 statistical software (IBM, Chicago, IL, USA). Data were analyzed by one-way analysis of variance with least significant difference (LSD) at the $\mathrm{p}=0.05$ confidence level.

\section{Results and Discussion}

Photosynthetic Pigment Contents in L. esculentum seedlings. The chlorophyll $a$, chlorophyll $b$, total chlorophyll and carotenoid contents of G1, G2 and G3 were lower than the CK. The G3 have a most decreased, the chlorophyll a, chlorophyll $b$, total chlorophyll and carotenoid contents of G1 decreased by $10.96 \%(p>0.05), 13.20 \%(p>0.05), 11.48 \%(p>0.05)$ and $20.71 \%(p>0.05)$, respectively, compared with $\mathrm{CK}$, and the photosynthetic pigment content of G3 has a slight decreased than the CK, the chlorophyll $a$, chlorophyll $b$, total chlorophyll and carotenoid contents decreased by $2.34 \%(p>0.05), 8.25 \%(p>0.05), 11.48 \%(p>0.05)$ and $4.44 \%(p>0.05)$, respectively, compared with CK, The order of chlorophyll a/b was G2> G3 > G1 > CK. It shows that grafting plant will affecting the photosynthetic rate, thus affecting the content of photosynthetic pigment, the chloroplast membrane of seedlings will be damaged under Cd stress, reducing the chloroplast photosynthetic enzyme content, causing leaf stomatal closure, obstructed photosynthesis, photosynthesis intensity decreases significantly, which leads to the decreased of chlorophyll content of plants, and grafting can improve the resistance of crops, such as low temperature, heavy metal stress.

Photosynthetic Characteristics of $L$. esculentum seedlings. Compared with the CK, The Pn of $L$. esculentum seedlings after grafted decreased to some extent under Cd stress, G1, G2 and G3 were decreased by $4.14 \%(p<0.05), 4.89 \%(p<0.05)$ and $11.78 \%(p<0.05)$, it showed that grafting has 
inhibitory effect on Photosynthetic rate. Leaf Gs sequence were ranked as $\mathrm{CK}>\mathrm{G} 2>\mathrm{G} 3>\mathrm{G} 1$, leaf $\mathrm{Ci}$ sequence were ranked as $\mathrm{CK}>\mathrm{G} 1>\mathrm{G} 2>\mathrm{G} 3$, showed that a large number of stomata are closed under Cd stress; G3 increased in leaves of Tr under Cd stress, increased by $1.54 \%(p>0.05)$ compared to $\mathrm{CK}$, the higher Pn can be decreasing leaf temperature, has a certain effect on alleviating under $\mathrm{Cd}$ stress, while Vpdl increased compared with CK, the G1 reached the highest, $53.11 \%(p>0.05)$ higher than the CK.

Table 1 Photosynthetic pigment contents in L. esculentum seedlings

\begin{tabular}{|c|c|c|c|c|c|}
\hline Treatments & $\begin{array}{c}\text { Chlorophyll } a \\
(\mathrm{mg} / \mathrm{g})\end{array}$ & $\begin{array}{c}\text { Chlorophyll } b \\
(\mathrm{mg} / \mathrm{g})\end{array}$ & $\begin{array}{c}\text { Total chlorophyll } \\
(\mathrm{mg} / \mathrm{g})\end{array}$ & $\begin{array}{c}\text { Chlorophyll } \\
a / b\end{array}$ & $\begin{array}{c}\text { Carotenoid } \\
(\mathrm{mg} / \mathrm{g})\end{array}$ \\
\hline CK & $1.579 \pm 0.006 \mathrm{a}$ & $0.485 \pm 0.050 \mathrm{a}$ & $2.064 \pm 0.044 \mathrm{a}$ & 3.270 & $0.338 \pm 0.034 \mathrm{a}$ \\
\hline G1 & $1.542 \pm 0.048 \mathrm{a}$ & $0.445 \pm 0.020 \mathrm{a}$ & $1.987 \pm 0.068 \mathrm{a}$ & 3.464 & $0.323 \pm 0.003 \mathrm{a}$ \\
\hline G2 & $1.541 \pm 0.132 \mathrm{a}$ & $0.407 \pm 0.086 \mathrm{a}$ & $1.948 \pm 0.046 \mathrm{a}$ & 3.906 & $0.305 \pm 0.021 \mathrm{a}$ \\
\hline G3 & $1.406 \pm 0.095 \mathrm{a}$ & $0.421 \pm 0.048 \mathrm{a}$ & $1.827 \pm 0.047 \mathrm{a}$ & 3.376 & $0.268 \pm 0.011 \mathrm{a}$ \\
\hline
\end{tabular}

Values are means \pm standard errors. Means with the same letter within each grafting times are not significantly different at $\mathrm{p}<0.05$.

Table 2 Photosynthetic characteristics of L. esculentum seedlings

\begin{tabular}{|c|c|c|c|c|c|}
\hline Treatments & $\begin{array}{c}\mathrm{Pn} \\
\left(\mu \mathrm{mol} \mathrm{CO} / \mathrm{m}^{2} / \mathrm{s}\right)\end{array}$ & $\begin{array}{c}\mathrm{Gs} \\
(\mathrm{mol} \\
\left.\mathrm{H}_{2} \mathrm{O} / \mathrm{m} / \mathrm{s}\right)\end{array}$ & $\begin{array}{c}\mathrm{Ci} \\
(\mu \mathrm{mol} \mathrm{CO} / \mathrm{mol})\end{array}$ & $\begin{array}{c}\mathrm{Tr} \\
(\mathrm{mmol} \\
\left.\mathrm{H}_{2} \mathrm{O} / \mathrm{m}^{2} / \mathrm{s}\right)\end{array}$ & $\begin{array}{c}\text { Vpdl } \\
(\mathrm{kPa})\end{array}$ \\
\hline $\mathrm{CK}$ & $19.950 \pm 0.141 \mathrm{a}$ & $0.385 \pm 0.109 \mathrm{a}$ & $341.559 \pm 6.312 \mathrm{a}$ & $4.356 \pm 0.873 \mathrm{a}$ & $1.608 \pm 0.392 \mathrm{a}$ \\
\hline $\mathrm{G} 1$ & $19.125 \pm 0.177 \mathrm{ab}$ & $0.245 \pm 0.119 \mathrm{a}$ & $329.198 \pm 9.709 \mathrm{a}$ & $3.891 \pm 1.121 \mathrm{a}$ & $2.462 \pm 1.038 \mathrm{a}$ \\
\hline $\mathrm{G} 2$ & $18.975 \pm 0.106 \mathrm{~b}$ & $0.293 \pm 0.167 \mathrm{a}$ & $253.437 \pm 1.031 \mathrm{~b}$ & $4.225 \pm 1.123 \mathrm{a}$ & $1.939 \pm 1.118 \mathrm{a}$ \\
\hline $\mathrm{G} 3$ & $17.600 \pm 0.212 \mathrm{c}$ & $0.290 \pm 0.041 \mathrm{a}$ & $244.152 \pm 0.434 \mathrm{~b}$ & $4.423 \pm 0.248 \mathrm{a}$ & $1.690 \pm 0.080 \mathrm{a}$ \\
\hline
\end{tabular}

Values are means \pm standard errors. Means with the same letter within each grafting times are not significantly different at $\mathrm{p}<0.05$.

Soluble Sugar Contents in $\mathbf{L}$. esculentum seedlings. Compared with CK, the soluble sugar content of the L. esculentum seedlings roots, stems, leaves and shoots were increased significantly under Cd stress, G1, G2 and G3 increased the soluble sugar content in roots by $15.92 \%(p>0.05)$, 9.91\% ( $p>0.05)$ and 2.67\% ( $p>0.05)$, the soluble sugar content in stems of L. esculentum seedlings were ranked as $\mathrm{G} 1>\mathrm{G} 3>\mathrm{CK}>\mathrm{G} 2$, compared with $\mathrm{CK}, \mathrm{G} 1, \mathrm{G} 2$ and G3 increased the soluble sugar content in leaves by $83.03 \%(p<0.05), 50.26 \%(p<0.05)$ and $27.77 \%(p<0.05)$, and the soluble sugar content in shoots of $L$. esculentum seedlings were ranked as G1 > G2 > G3 > CK. This result revealed that the concentration of soluble sugar varied greatly at different grated times, there was a reason that the stock incompatible with scion, the content of soluble sugar have a obviously decreased after continuous grafted.

Table 3 Soluble sugar contents in L. esculentum seedlings

\begin{tabular}{|c|c|c|c|c|}
\hline Treatments & $\begin{array}{c}\text { Roots } \\
(\mathrm{mg} / \mathrm{g})\end{array}$ & $\begin{array}{c}\text { Stems } \\
(\mathrm{mg} / \mathrm{g})\end{array}$ & $\begin{array}{c}\text { Leaves } \\
(\mathrm{mg} / \mathrm{g})\end{array}$ & $\begin{array}{c}\text { Shoots } \\
(\mathrm{mg} / \mathrm{g})\end{array}$ \\
\hline CK & $79.215 \pm 3.029 \mathrm{a}$ & $59.744 \pm 0.482 \mathrm{~b}$ & $42.400 \pm 0.593 \mathrm{~d}$ & $51.421 \pm 1.379 \mathrm{c}$ \\
\hline $\mathrm{G} 1$ & $91.824 \pm 7.704 \mathrm{a}$ & $75.364 \pm 1.832 \mathrm{a}$ & $77.606 \pm 2.377 \mathrm{a}$ & $76.577 \pm 2.060 \mathrm{a}$ \\
\hline $\mathrm{G} 2$ & $87.067 \pm 6.530 \mathrm{a}$ & $57.729 \pm 0.947 \mathrm{~b}$ & $63.710 \pm 0.659 \mathrm{~b}$ & $60.646 \pm 1.137 \mathrm{~b}$ \\
\hline $\mathrm{G} 3$ & $81.330 \pm 6.920 \mathrm{a}$ & $60.751 \pm 5.363 \mathrm{~b}$ & $54.175 \pm 1.769 \mathrm{c}$ & $57.447 \pm 3.364 \mathrm{~b}$ \\
\hline
\end{tabular}

Values are means \pm standard errors. Means with the same letter within each grafting times are not significantly different at $\mathrm{p}<0.05$. 


\section{Conclusions}

Under Cd stress, G1, G2 and G3 decreased the chlorophyll $a$, chlorophyll $b$, total chlorophyll and carotenoid content of the L. esculentum seedlings compared with $\mathrm{CK}$, and the total chlorophyll content of $L$. esculentum seedlings were ranked as $\mathrm{CK}>\mathrm{G} 1>\mathrm{G} 2>\mathrm{G} 3$. The continuous grafted decreased the Pn, Gs and $\mathrm{Ci}$ of L. esculentum seedlings, and increased the Vpdl, and the Pn were ranked as $\mathrm{CK}>\mathrm{G} 1>\mathrm{G} 2>\mathrm{G} 3$. Compared with $\mathrm{CK}$, the continuous grafted increased the soluble sugar contents in roots, stems, leaves and shoots of L. esculentum seedlings, and the soluble sugar contents in roots and shoots were ranked as G1 $>\mathrm{G} 2>\mathrm{G} 3>\mathrm{CK}$. Therefore, cutting after continuous grafted is unfavorable for the growth of the L. esculentum seedlings under Cd stress.

\section{Acknowledgements}

This work was financially supported by the Undergraduate Student Research Interesting Training Program of Sichuan Agricultural University (2016).

\section{References}

[1] X.F. Zhang, H.P. Xia, Z.A. Li, P. Zhuang and B. Gao: Journal of Hazardous Materials Vol. 189 (2011), p. 414.

[2] L. L. Sun, Y. Xu, S. R. Guo, H. Li, S. Su, P. Gao and J. Sun. Journal of Nanjing Agricultural University Vol. 37(2014), p. 55.

[3] S. L. Wang: Shanxi Fruits Vol. 5(2009), p. 29.

[4] J. Wang, L. Jin, L. Luo, M. Liao, X. Lv, Z. Wang, D. Liang and H. Xia: Environmental Monitoring and Assessment Vol. 188 (2016), p. 82.

[5] Y.C. Dai, J.L. Lv, Y.F. Cao, K. Liu and R.L. Zhang. Journal of Agro-Environment Science Vol. 33(2014), p. 514.

[6] Y. Liu, L. Lin, Q. Jin and X. Zhu: Environmental Progress \& Sustainable Energy Vol. 34 (2015), p. 663.

[7] J. Shi, R.P. Hu, X.D. Chu, C.C. Li, J. Zhang and L.J. Lin: Shanxi Journal of Agricultural Sciences Vol. 62 (2015), p. 1.

[8] Z.B. Hao, J. Chang and Z. Xu: Plant Physiology Experiment (Harbin Institute of Technology Press, China 2004). 